\title{
Acute myeloid leukemia
}

\section{Author:}

Nelson Hamerschlak, MD PhD

Hematology and Bone Marrow

Transplant Dept

Hospital Israelita Albert Einstein

Av. Albert Einstein, 627/520

São Paulo (SP) - Brazil

CEP 05651-901

\section{Abstract}

Acute myeloid leukemia (AML) occurs with a frequency of 3.5/1,000,000/year cases. AML patients have an invasion of diseased cells (blasts) medullary insufficiency, microenvironmental dysfunction, defects in the proliferation and function of the remaining normal cells, and global dysfunction of the immune system, and may present fatigue, fever, blotches on the body, and bone or joint pain. The diagnosis must be made based on clinical, morphological, immunophenotypical, molecular, and cytogenetic findings. Prognostic assessment can determine the choice of treatment for the patient, and it depends on many different patient-related factors. Traditionally, the karyotype has been used as the principal prognostic factor in de novo leukemias. The conventional treatment for AML is divided between induction and consolidation. The future of AML treatment, particularly in cases of more reserved prognoses, should count on the assistance of genomics with panels of genetic changes or sequencing, new drugs, and targeted therapy. This paper describes the various alternatives available and under investigation, in Brazil and worldwide. 


\section{Introduction}

Acute myeloid leukemia (AML) occurs with a frequency of 3.5 cases per million people per year, and its incidence increases with age. This increase is significant after 60 years of age and the average age of occurrence is around 65 years of age. ${ }^{1-3}$ In Brazil, according to the National Cancer Institute (Inca), there are an estimated 8000 to 9000 cases per year. ${ }^{4}$

It is known that the occurrence of AML can be linked to different factors, such as ionizing radiation, exposure to chemical products, prior exposure to chemotherapy drugs, genetic factors, congenital diseases, and medullary failure syndromes. But, in most cases, these factors are not identified. ${ }^{5}$

From a physiological perspective, the effects of the disease occur through the invasion of diseased cells (blasts), medullary insufficiency, microenvironmental dysfunction, defects in the proliferation and function of the remaining normal cells, and global dysfunction of the immune system. The disease is characterized, at the end, by peripheral cytopenias and invasion by blastic cells. ${ }^{6}$

\section{Diagnosis}

The diagnosis must be made based on clinical, morphological, immunophenotypical, molecular, and cytogenetic findings. ${ }^{7}$ Clinically, patients may present fatigue, fever, blotches on the body, and bone or joint pain. The physical exam should check for paleness, mucocutaneous bleeding, fever, and visceromegalies. More rarely, patients may experience infiltration of the skin, gums, extramedullary tumors, and signs of infiltration of the central nervous system, manifested as headache or paralysis of the cranial nerves. ${ }^{6}$

For a morphological analysis, counts of 200 leukocytes in the peripheral blood and 500 nucleated cells in the bone marrow are recommended. According to World Health Organization criteria, when the number of blasts is equal to or greater than $20 \%$ it is considered to be AML, except in cases of $t(15: 17), \quad t(8: 21), \quad$ inversion of chromosome 16 , or $\mathrm{t}(16: 16){ }^{7}$

$$
\text { The objectives of }
$$
immunophenotyping are to analyze cell lines, to characterize the state of cell maturation, and to detect anomalous immunophenotypical expressions that could be useful in monitoring minimal residual disease. Table 1 displays the principal markers for a diagnosis of AML. ${ }^{8-10}$

Various cytogenetic changes can occur in AML, among which monosomal and complex changes are described as very serious. Chart 1 shows the cytogenetic changes of special interest in AMLs. ${ }^{8-10}$

We usually classify AMLs as de novo or secondary to myelodysplasia and/or chemotherapy or radiotherapy, 
the latter having a worse prognosis. The

French-American-British

classification was used for many years, taking only morphological characteristics into account and dividing the AMLs into M0, M1, M2, M3, M4, M5, M6, and M7 (Table 2), while the World Health Organization classification of 2008 is currently in effect and is based on risk (Chart 2). ${ }^{11}$

\section{Prognostic factors}

In AML, perhaps one of the most important steps is the prognostic assessment, because this can determine the choice of treatment for the patient. Several studies have been published in this regard and they usually consider patient-related factors, such as performance status, age, comorbidities, the existence of a compatible donor, factors related to the biology of the disease such as chromosomal changes, response to therapy, secondary versus $d e$ novo leukemia, morphology (FAB classification), immunophenotype, genetic-molecular factors, and even factors related to the environment, such as socioeconomic resources and conditions.

Traditionally, the karyotype has been used as the principal prognostic factor in de novo leukemias. Table 3 separates the cases into favorable, unfavorable, and intermediate prognoses according to karyotype..$^{8-10}$ Keeping in mind that more than $40 \%$ of the AMLs have a normal karyotype and knowing about the variability of their evolution in these patients, the description of geneticmolecular factors and mutations, such as NPM1 in 55\% of cases, FLT3-ITD (40\%), MLL-PTD (6\%), NRAS (810\%), CEBPA (10\%), and FLT3-TKD (6\%), can contribute to the improvement of prognostic measurements. ${ }^{12-15}$ Of these, FLT3-ITD, NPM1, and CBPA are the ones that have been more often used in clinical practice. ${ }^{12-15}$ The presence of the c-Kit mutation has also been used in order to demonstrate cases of $t(8: 21)$ or inv(16) with poor prognosis. ${ }^{16} 15$

Therefore, a normal karyotype with negative FLT3 and positive NPM1 and those with CBPA and with inv16, $t(8: 21)$ without mutation of the c-Kit are considered to be factors for good patient prognosis. The others are considered to be of an intermediate or unfavorable prognosis. ${ }^{16}$ The European Leukemia $\mathrm{Net}^{17}$ then went on the classify AMLs as having favorable, intermediate I, intermediate II, and unfavorable prognoses, as displayed in Table 4 . In our service, we have adopted the algorithm in Figure 1 for an indication of consolidation chemotherapy with autologous or allogeneic bone marrow transplants. We take the c-Kit into account for cases of $t(8 ; 21)$, inv(16), or $t(16 ; 16)$.

New changes have been identified and their value in the clinical management of AML has been studied: mutations of TET2, ASXL1, IDH1 and IDH2, PHF6, and DNMT3A. ${ }^{18-22}$ It 
appears that the mutation of IDH2 R140, but not of IDH2 R172 or IDH1, was associated with an improvement in overall survival. Mutations of ASXL1 and PHF6, on the other hand, were associated with a worsening of overall survival. ${ }^{18-22}$ Recently, a meta-analysis of studies including more than 4500 patients with AML showed that DNMT3A is associated with subtypes M4 and M5 and that it was an independent adverse marker. The authors of that study recommended incorporating this mutation in the decision algorithms for patients with AML. $^{23}$

\section{Treatment}

The conventional treatment for AML is divided between induction and consolidation. The conventional induction treatment with anthracycline and cytarabine has been in use for more than 40 years. Studies with the addition of other drugs or increased doses of cytarabine have not reported any increase in remission rates, which ranged from 60 to $80 \% .^{24,25}$ The anthracyclines traditionally used are idarubicin and daunorubicin. $^{24,25}$ In consolidation therapy, the use of two to four cycles of cytarabine in high doses, autologous transplants, and allogeneic transplants have been used depending on the prognosis of the patient. ${ }^{26,27}$

The future of AML treatment, particularly in cases of more reserved prognoses, should count on the assistance of genomics with panels of genetic changes or sequencing, new drugs, and targeted therapy. Today, some of these strategies are already being used in clinical studies, such as the use of FLT3 inhibitors, ATRA (all-trans retinoic acid) together with chemotherapy in the presence of NPM1, the use of hypomethylation agents for secondary leukemias and in elderly patients, histone deacetylase inhibitors, $\mathrm{AKT} / \mathrm{m}$ Tor inhibitors, clofarabine, apoptopic agents, such as genasense, and MDR modulators, such as zosuquidar. $^{27,28}$

\section{Acute myeloid leukemia}

Acute myeloid leukemia, designated as FAB classification subtype M3, accounts for between $10 \%$ and $15 \%$ of AMLs. Morphologically, it is characterized by the presence of abnormal promyelocytes, with eccentric nuclei and granulations in the cytoplasm, as well as numerous Auer rods in bundle formations. Immunophenotypically, there is high expression of myelomonocytic antigens (CD13, CD15 and CD33) and the absence of expression of monocytic antigens (CD14, including My4, Leu M3, and Mo2) and HLA-DR. The presence of the $t(15: 17)$ (q22: q21) translocation occurs in practically all cases and results in the fusion of the PML and RARa genes. ${ }^{29}$

Clinically, acute promyelocytic leukemia is characterized by disseminated intravascular coagulation, 
with hemorrhage being the main cause of death in these patients. Treatment has changed significantly with the advent of ATRA associated with chemotherapy. ${ }^{29,30}$

The Spanish group (PETHEMA) developed a treatment protocol showing the importance of anthracyclines in combination with ATRA in the evolution and cure of the disease and established a risk classification based on leukocyte and platelet counts, providing individualized therapy for each case with good chances of a cure. ${ }^{31}$

Conventional treatment consists of induction, consolidation, and maintenance. Arsenic trioxide (ATO) is often used in patients suffering from recurrent disease, but there are several studies that combine ATRA and ATO in the first line, mainly for low-risk cases, with outcomes similar to those from the use of ATRA and chemotherapy. ${ }^{32}$

\section{Leukemias in the elderly}

Normally, AML treatment outcomes in the elderly are very bad. Many times these patients have compromised performance status, a high incidence of minimum residual disease following treatment, unfavorable cytogenetics, high treatment-related mortality, higher incidence of induction failure, shorter remissions, and shorter overall survival. $^{33,34}$

The aging population, which in most cases reaches an advanced age under the proper clinical conditions, is forcing the world to adapt to more aggressive treatment strategies. Adequate geriatric evaluation, comorbidity rates, and less toxic treatment schemes are making curative treatment possible for these patients. ${ }^{35}$

In induction, we must consider the standard $3+7$ (anthracycline + cytarabine) regimen, with remission rates of $60 \%$, always remembering that progression-free survival is short (5 to 10 months) and that remission is maintained for more than 2 years in less than $10 \%$ of cases. ${ }^{36-38}$ It is important to consider using hypomethylating agents, such as 5-azacytidine and decitabine, mainly in more fragile patients or those with secondary leukemias. Of note here are the studies with high doses of decitabine and rates of complete remission of around $50 \% .{ }^{39}$

In the consolidation of elderly patients, those with favorable prognoses should be considered, i.e., those who do not present $\mathrm{t}(15 ; 17), \mathrm{t}(8: 21)$, and inv16, with negative c-Kit, or normal karyotype with negative FLT3 and positive NPM1. They should be submitted to consolidations with intermediate doses of cytarabine, with 1 to $1.5 \mathrm{~g}$ every 12 hours for 3 days or an autologous transplant. Those with unfavorable prognoses and a good overall geriatric assessment should be selected (if under 80 years of age) for non-myeloablative or reduced intensity transplants. ${ }^{40-42}$ 


\section{Acute myeloid leukemia and} bone marrow transplants in Brazil

Data from several Brazilian authors report discouraging outcomes from the treatment of AML in Brazil. ${ }^{43}$ 41 Since 2005, the Brazilian Bone Marrow Transplant Society (SBTMO) has encouraged multicenter studies and the evaluation of various treatment centers in Brazil with the goal of monitoring and trying to improve bone marrow transplant outcomes.

Several initiatives can be highlighted here. Between 2005 and 2007, data from 1289 patients in 17 treatment centers in São Paulo, Rio de Janeiro, Paraná, Pernambuco, and Rio Grande do Sul were evaluated retrospectively. Transplants for AML accounted for $16 \%$ of the transplants performed in Brazil, and in the same period, the data of the Center for International Blood and Marrow Transplant Research (CIBMTR) was 27\%. The results were partially published and can be seen in Figures 2 and 3 for allogeneic and autologous transplants, respectively. The conditioning regimens were mainly busulfan and cyclophosphamide, busulfan and melphalan, and TBI (total body irradiation) and cyclophosphamide. ${ }^{44}$

In this study, there was no prognostic cytogenetic classification and in general the autologous transplant had interesting results very similar to those of the allogeneic transplant. This is an interesting piece of information and should be analyzed within the context that, at least during this period, Brazil followed the more European than North American trend to value this type of procedure. The similarity of the survival data between the two transplant modalities was explained by higher mortality in the autologous transplants from recurrence (60\%) than from toxicity $(40 \%)$, with the percentages reversed for allogeneic transplants. ${ }^{44 .}$

The Brazilian post-transplant survival data were subsequently validated by Marcelo Pasquini of the CIBMTR, who published the curves for early, intermediate, and advanced disease from the Brazilian data forwarded to the CIBMTR, as shown in Figure 4.

From 2007 to 2012, several initiatives in Brazil in this area deserve mention:

- Experience with the use of oral or intravenous busulfan in association with fludarabine, ${ }^{45,46}$

- A study to evaluate how patients with AML were treated in Brazil; ${ }^{47}$ - A study of elderly patients with bone marrow transplants with a regimen of reduced toxicity; ${ }^{48}$

\footnotetext{
* Pasquini M. Resultados de transplantes de medulla óssea de centros de transplante brasileiros através dos registros do Center for International Blood and Marrow Transplant Research (CIBMTR). [Presented during the Brazilian Bone Marrow Transplant ConferenceSBTMO 2007].
} 
- Two consensuses (2009 and 2012) on bone marrow transplants from the Brazilian Bone Marrow Transplant Society. ${ }^{49,50}$

The group known as the "Conexão Caipira", led by the Centro de Transplantes de Jaú, showed that the use of oral busulfan and fludarabine produced a survival curve of $64 \%$ in two years (Figure 5). ${ }^{45}$ The results with intravenous busulfan and fludarabine, mainly in elderly patients, were published by our group, showing their effectiveness (Figure 6) and low toxicity (Figure 7). ${ }^{46}$

With the objective of evaluating the conditions under which patients with AML are diagnosed and treated in Brazil, a questionnaire was sent to the Brazilian treatment centers. The results obtained showed that: ${ }^{47}$

- The centers considered to be references and that perform bone marrow transplants use diagnostic and prognostic methods for more than $90 \%$ of their patients, while in other places, cytogenetics and immunophenotyping for diagnosis are lacking, with only $50 \%$ of the institutions that treat patients but do not perform transplants using these methodologies;

- In relation to molecular studies, the PML/RARa was conducted or forwarded for execution by more than $80 \%$ of the institutions consulted, while the FLT3 by $45 \%$ and the NPM1 by less than $15 \%$ of them;

- Induction therapy with cytarabine and idarubicin was used by $36 \%$ of the institutions, and daunorubacin and cytarabine by $64 \%$ of them;

- In consolidation, $91 \%$ of the institutions indicated allotransplant for intermediate risk and $100 \%$ for high risk patients, when a donor was identified;

- In low risk patients, $70 \%$ were consolidated with high doses of cytarabine and $30 \%$ with bone marrow autotransplants.

Transplants in the elderly are becoming an increasingly more common practice in Brazil. The first Brazilian initiative was conducted by our institution in association with the MD Anderson Cancer Center, in a study published in 2011, the results of which showed significant survival in patients between 60 and 80 years of age. ${ }^{48}$ The two-year survival of treated patients reached $71 \%$ in those in first remission, $44 \%$ in those in second remission, and $32 \%$ in those with active disease. Interestingly, we found that $58 \%$ died from recurring disease and not from the toxicity of the transplant (42\%). ${ }^{48}$

The work of the Latin-American consortium, coordinated by Professor Eduardo Rego, in collaboration with the American Hematology Association, to improve the outcomes of acute promyelocytic leukemias, was a significant milestone in the area of 
leukemia in Brazil. Using a protocol from a Spanish risk-based classification (PETHEMA) and from agile and centralized molecular diagnosis laboratories, it achieved outcomes in developing countries similar to those observed at the international level, as shown in Figure 8. ${ }^{51}$

Finally, during the period from 2012 to 2015, initiatives such as targeted-dose busulfan, improvements in our diagnostic/prognostic tools, the 2015 Consensus of the Brazilian Society of Bone Marrow Transplants (SBTMO), consolidating the consensuses of 2009 and 2012 and as yet unpublished, ${ }^{49,50}$ and the design of a protocol to evaluate the autotransplant versus chemotherapy in the consolidation of low-risk patients, demonstrated that specialists continue to be active in Brazil, always seeking better diagnostic, prognostic, and therapeutic conditions.

The SBTMO held expert meetings in 2009, 2012, and 2015 to establish a consensus for bone marrow transplants in Brazil around indications, conditioning regimens, prophylaxis, and treatment of the graft-versus-host disease. The key recommendations for AML were: $:^{50,52}$

1. To base indications of allogeneic transplants, autologous transplants, and consolidation chemotherapy in the first remission on the prognostic factors of the patients. Thus, patients with intermediate and unfavorable prognoses would be directed to allogeneic transplants, while those with favorable prognoses to consolidation chemotherapy with high doses of cytarabine or autologous transplant;

2. In spite of the knowledge that, in the second remission or in advanced or even refractory disease, the transplant has a worse prognosis, they accept it under these conditions;

3. The main conditioning regimens recommended would be busulfan and cyclophosphamide and busulfan and fludarabine, and whenever possible, busulfan dosing would be recommended;

4. Transplants in the elderly are indicated in patients in good overall condition and with few comorbidities, preferably with an extensive geriatric assessment.

Achieving the proper levels of busulfan seems to influence the outcome of transplants. Therefore, doses in the area under the curve (AUC) of 6000 $\mu$ Mol.min can be used in patients with more aggressive diseases, younger patients, or even those with active disease, while doses of $4000 \mu \mathrm{Mol}$.min are ideal in transplants of low toxicity used in patients with myelofibrosis, in AML with comorbidities, and in the elderly. ${ }^{53}$

In Brazil, dosing of busulfan is not routinely performed. It is indicated especially when using oral busulfan, where absorption is erratic. However, 
few treatment centers have the HPLC (high performance or pressure liquid chromatography) or UPLC (ultra performance) technology to perform the dosing. With the goal of trying to obtain dosing prior to the transplants that would be capable of predicting the dose to be administered to patients, the doctoral thesis of Iracema Esteves was conducted with technology developed at Einstein through the Ministry of Health's PROADI program. ${ }^{53}$ A prior dosing was performed from 48 hours to 15 days before the transplant, comparing it with the dosing during the procedure. She showed that this strategy was feasible for the use of intravenous busulfan, but not accurate for oral use of the drug. ${ }^{53}$

Another project conducted with PROADI resources was the implementation of FLT3, NPM1, CEBPA, and c-Kit prognostic molecular tests in Brazil and making them available to both public and private services. We were able to observe that the incidence of FLT3, NPM1, and CEBPA in patients with normal karyotypes were $19 \%, 17 \%$, and $1 \%$, respectively. The c-Kit mutation among cases of $\mathrm{t}(8: 21)$ or chromosome 16 inversion was $3 \%$. Using cytogenetic tools and these molecular findings, we were able to classify out patients according to the European Leukemia Net, ${ }^{54}$ as shown in Figure 9.

Based on the excellent results obtained in the acute promyelocytic leukemia consortium and on the fact that, for Brazil, the autologous transplant may be a more suitable consolidation strategy for low-risk patients, a group of Brazilian researchers, led by Eduardo Rego, intends to conduct a multicenter study to evaluate the best consolidation strategy, i.e., chemotherapy with high doses of cytarabine versus an autotransplant of hematopoietic stem cells.

After conducting a retrospective review of the literature regarding the results obtained in the treatment of AML and the efforts made in Brazil towards this end, the scientific community is hopeful that we will continue to achieve better results. We should remember, however, that in our country there exist enormous inequalities and often unfavorable conditions, causing distortions that should gain the attention of our authorities so they can be corrected. 


\section{References}

1. Yamamoto JF, Goodman MT. Patterns of leukemia incidence in the United States by subtype and demographic charactheristics, 1997-2002. Cancer Causes Control. 2008;19(4):379-90.

2. Siegel R, Naishadham D, Jemal A. Cancer statistics, 2013. CA Cancer J Clin. 2013;63(1):11-30.

3. Appelbaum FR, Gundacker H, Head DR, Slovak ML, Willman CL, Godwin JE, et al. Age and acute myeloid leukemia. Blood. 2006;107(9):3481-5.

4. Brasil. Ministério da Saúde. Instituto Nacional do Câncer José Alencar Gomes da Silva. Estimativas 2012: incidência de câncer no Brasil. Rio de Janeiro: INCA; 2011. Disponível em: http://portal.saude.sp.gov.br/resources/ses /perfil/gestor/homepage/estimativas-deincidencia-de-cancer-

2012/estimativas_incidencia_cancer_201 2.pdf. Acessado em 2015 (19 out).

5. Linet MS. The leukemias: epidemiologic aspects. New York: Oxford University Press; 1985.

6. Löwenberg B, Downing JR, Burnett A. Acute myeloid leukemia. N Engl J Med. 1999;341(14):1051-62.

7. Vardiman JW, Thiele J, Arber DA, Brunning RD, Borowitz MJ, Porwit A, et al. The 2008 revision of the World Health Organization (WHO) classification of myeloid neoplasms and acute leukemia: rationale and important changes. Blood. 2009;114(5):937-51.

8. Grimwade D, Walker H, Oliver F, Wheatley K, Harrison C, Harrison G, et al. The importance of diagnostic cytogenetics on outcome in AML: analysis of 1,612 patients entered into the MRC AML 10 trial. The Medical Research Council Adult and Children's Leukaemia Working Parties. Blood. 1998;92(7):2322-33.

9. Byrd JC, Mrózek K, Dodge RK, Carroll AJ, Edwards CG, Arthur DC, et al. Pretreatment cytogenetic abnormalities are predictive of induction success, cumulative incidence of relapse, and overall survival in adult patients with de novo acute myeloid leukemia: results from Cancer and Leukemia Group B (CALGB 8461). Blood. 2002;100(13):4325-36.

10. Marcucci G, Mrózek K, Ruppert AS, Archer KJ, Pettenati MJ, Heerema NA, et al. Abnormal cytogenetics at date of morphologic complete remission predicts short overall and disease-free survival, and higher relapse rate in adult acute myeloid leukemia: results from cancer and leukemia group B study 8461. J Clin Oncol. 2004;22(12):2410-8. 
11. Yin CC, Medeiros LJ, Bueso-Ramos

CE. Recent advances in the diagnosis and classification of myeloid neoplasms-comments on the 2008 WHO classification. Int $\mathrm{J}$ Lab Hematol. 2010;32(5):461-76.

12. Kottaridis PD, Gale RE, Frew ME, Harrison G, Langabeer SE, Belton AA, et al. The presence of a FLT3 internal tandem duplication in patients with acute myeloid leukemia (AML) adds important prognostic information to cytogenetic risk group and response to the first cycle of chemotherapy: analysis of 854 patients from the United Kingdom Medical Research Council AML 10 and 12 trials. Blood. 2001;98(6):1752-9.

13. Schnittger S, Schoch C, Dugas M, Kern W, Staib P, Wuchter C, et al. Analysis of FLT3 length mutations in 1003 patients with acute myeloid leukemia: correlation to cytogenetics, FAB subtype, and prognosis in the AMLCG study and usefulness as a marker for the detection of minimal residual disease. Blood. 2002;100(1):5966

14. Thiede C, Steudel C, Mohr B, Schaich M, Schäkel U, Platzbecker U, et al. Analysis of FLT3-activating mutations in 979 patients with acute myelogenous leukemia: association with FAB subtypes and identification of subgroups with poor prognosis. Blood. 2002;99(12):4326-35.
15. Falini B, Mecucci C, Tiacci E, Alcalay M, Rosati R, Pasqualucci L, et al. Cytoplasmic nucleophosmin in acute myelogenous leukemia with a normal karyotype. N Engl J Med. 2005;352(3):254-66.

16. Marcucci G, Haferlach T, Döhner H. Molecular genetics of adult acute myeloid leukemia: prognostic and therapeutic implications. J Clin Oncol. 2011;29(5):475-86.

17. Döhner H, Estey EH, Amadori S, Appelbaum FR, Büchner T, Burnett AK, et al. Diagnosis and management of acute myeloid leukemia in adults: recommendations from an international expert panel, on behalf of the European LeukemiaNet. Blood. 2010;115(3):45374.

18. Abdel-Wahab O, Mullally A, Hedvat C, Garcia-Manero G, Patel J, Wadleigh $\mathrm{M}$, et al. Genetic characterization of TET1, TET2, and TET 3 alterations in myeloid malignancies. Blood. 2009;114(1):144-7.

19. Van Vlierberghe P, Patel J, AbdelWahab O, Lobry C, Hedvat CV, Balbin $\mathrm{M}$, et al. PHF6 mutations in adult acute myeloid leukemia. Leukemia. 2011;25(1):130-4.

20. Carbuccia N, Murati A, Trouplin V, Brecqueville M, Adélaïde J, Rey J, et al. 
Mutations of ASXL1 gene in myeloproliferative neoplasms. Leukemia. 2009;23(11):2183-6.

21. Patel JP, Gönen M, Figueroa ME, Fernandez H, Sun Z, Racevskis J, et al. Prognostic relevance of integrated genetic profiling in acute myeloid leukemia. $\mathrm{N}$ Engl J Med. 2012;366(12):1079-89.

22. Green CL, Evans CM, Zhao L, Hills RK, Burnett AK, Linch DC,et al. The prognostic significance of IDH2 mutations in AML depends on the location of the mutation. Blood. 2011;118(2):409-12.

23. Shivarov V, Gueorguieva R, Stoimenov A, Tiu R. DNMT3A mutation is a poor prognosis biomarker in AML: results of a meta-analysis of 4500 AML patients. Leuk Res. 2013;37(11):1445-50.

24. Stein EM, Tallman MS. Remission induction in acute myeloid leukemia Int $\mathbf{J}$ Hematol. 2012;96(2):164-70.

25. Schlenk RF. Post-remission therapy for acute myeloid leukemia. Haematologica. 2014;99(11):1663-70.

26. Estey EH. Acute myeloid leukemia: 2013 update on risk-stratification and management. Am J Hematol. 2013;88(4):318-27.

27. Pollyea DA, Gutman JA, Gore L, Smith CA, Jordan CT. Targeting acute myeloid leukemia stem cells: a review and principles for the development of clinical trials. Haematologica. 2014;99(8):1277-84.

28. Stein EM, Tallman MS. Novel and emerging drugs for acute myeloid leukemia. Curr Cancer Drug Targets. 2012;12(5):522-30.

29. Tallman MS, Nabhan C, Feusner JH, Rowe JM. Acute promyelocytic leukemia: evolving therapeutic strategies. Blood. 2002;99(3):759-67.

30. Ohno R, Asou N, Ohnishi K. Treatment of acute promyelocytic leukemia: strategy toward further increase of cure rate. Leukemia. 2003;17(8):145463.

31. Sanz MA, Martín G, González M, León A, Rayón C, Rivas C, et al. Riskadapted treatment of acute promyelocytic leukemia with all- trans-retinoic acid and anthracycline monochemotherapy: a multicenter study by the PETHEMA group. Blood. 2004;103(4):1237-43.

32. Lo-Coco F, Avvisati G, Vignetti M, Thiede C, Orlando SM, Iacobelli S, et al. Retinoic acid and arsenic trioxide for acute promyelocytic leukemia. N Engl J Med. 2013;369(2):111-21.

33. Ossenkoppele G, Löwenberg B. How I treat the older patient with acute 
myeloid leukemia. Blood. 2015;125(5):767-74.

34. Michaelis LC, Erba HP. Recent developments in the treatment of older individuals with acute myeloid leukemia: 2014. Curr Opin Hematol. 2015;22(2):108-15.

35. Kaur I, Constance JE, Kosak KM, Spigarelli MG, Sherwin CM. An extensive pharmacokinetic, metabolic and toxicological review of elderly patients under intensive chemotherapy for acute myeloid leukemia. Expert Opin Drug Metab Toxicol. 2015;11(1):53-65.

36. Walter RB, Estey EH. Management of older or unfit patients with acute myeloid leukemia. Leukemia. 2015;29(4):770-5.

37. Foran JM. Frontline therapy of AML: should the older patient be treated differently? Curr Hematol Malig Rep. 2014;9(2):100-8.

38. Hamerschlak N. Myeloid leukemia: are we getting better? Rev Bras Hematol Hemoter. 2015;37(1):3-4.

39. Ritchie EK, Feldman EJ, Christos PJ, Rohan SD, Lagassa CB, Ippoliti C, et al. Decitabine in patients with newly diagnosed and relapsed acute myeloid leukemia. Leuk Lymphoma. 2013;54(9):2003-7.
40. de Lima M, Couriel D, Thall PF, Wang X, Madden T, Jones R, et al.Oncedaily intravenous busulfan and fludarabine: clinical and pharmacokinetic results of a myeloablative, reducedtoxicity conditioning regimen for allogeneic stem cell transplantation in AML and MDS. Blood. 2004;104(3):85764.

41. Champlin R. Reduced-intensity allogeneic hematopoietic transplantation should be considered a standard of care for older patients with acute myeloid leukemia. Biol Blood Marrow Transplant. 2011;17(12):1723-4.

42. Farag SS, Maharry K, Zhang MJ , Pérez WS, George SL, Mrózek K, et al. Comparison of reduced-intensity hematopoietic cell transplantation with chemotherapy in patients age 60-70 years with acute myelogenous leukemia in first remission. Biol Blood Marrow Transplant. 2011;17(12):1796-803.

43. Capra M, Vilella L, Pereira WV, Coser VM, Fernandes MS, Schilling MA, et al. Estimated number of cases, regional distribution and survival of patients diagnosed with acute myeloid leukemia between 1996 and 2000 in Rio Grande do Sul, Brazil. Leuk Lymphoma. 2007;48(12):2381-6

44. Hamerschlak N, Barton D, Pasquini R, Sarquis YN, Ferreira E, Moreira FR, et al. Estudo retrospectivo do tratamento de 
leucemia mielóide aguda com o transplante de medula óssea $\quad: \quad$ a experiência brasileira [Retrospective study of stem cell transplantation for acute myeloid leukemia (AML): the Brazilian experience]. Rev Bras Hematol Hemoter. 2006;28(1):11-8.

45. Colturato VAR, Souza MP, Mauad MA, Paton EJA, Pieroni F, Stracieri ABLP, et al. Fludarabina e bussulfan (Flu-Bu): um regime de condicionamento de baixa toxicidade mesmo em uso de bussulfan via oral. A experiência do grupo Cooperativo Conexão Caipira. In: IX Congresso Brasileiro de Transplante de Medula Óssea, Campos do Jordão, 2005;27:33. [abstract].

46. Kerbauy FR, Rodrigues M, de Souza Santos FP, Sobrinho JN, Kutner JM, Torres MA, et al. Allogeneic hematopoietic stem cell transplant after intravenous busulfan and fludarabine conditioning. Leuk Lymphoma. 2011;52(2):321-4.

47. Helman R, Santos FPS, Simões B, Atta EH, Callera F, Dobbin JA, et al. Leucemia mieloide aguda: atualidade brasileira de diagnóstico e tratamento [Acute myeloid leukemia: update in diagnosis and treatment in Brazil]. Einstein (São Paulo). 2011;9(2 Pt 1):17983.

48. Alatrash G, de Lima M, Hamerschlak N, Pelosini M, Wang X, Xiao L, et al.
Myeloablative reduced-toxicity i.v. busulfan-fludarabine and allogeneic hematopoietic stem cell transplant for patients with acute myeloid leukemia or myelodysplastic syndrome in the sixth through eighth decades of life. Biol Blood Marrow Transplant. 2011;17(10):1490-6.

49. Silla LM, Dulley F, Saboya R, Paton E, Kerbauy FR, Arantes AM, et al. Hematopoietic stem cells transplantation and acute myeloid leukemia: Brazilian guidelines. Rev Bras Hematol Hemoter. 2010;32(suppl 1): 61-5.

50. Hamerschlak N, Bouzas LFS, Seber A, Silla L, Ruiz MA. Diretrizes da Sociedade Brasileira de Transplante de de Medula Óssea 2012. São Paulo; Sociedade Brasileira de Transplante de Medula Óssea, 2013.

51. Rego EM, Kim HT, Ruiz-Argüelles GJ, Undurraga MS, Uriarte Mdel R, Jacomo RH, et al. Improving acute promyelocytic leukemia (APL) outcome in developing countries through networking, results of the International Consortium on APL. Blood. 2013;121(11):1935-43.

52. Silla LMR, Dulley F, Saboya R, Paton E, Kerbauy F, Arantes AM, et al. Bone marrow transplantation and acute myeloid leukemia: Brazilian guidelines. Rev Bras Hematol Hemoter. 2013;35(1):56-61. 
53. Esteves I. Avaliação plasmática dos níveis de bussulfano em pacientes submetidos à Transplante de Células Tronco Hematopoiéticas. [Tese]. São Paulo: Universidade Federal de São Paulo; 2014.
54. Hamerschlak N, Pires F, Helman R, Datoguia T, Campregher PV, Oliveira W, et al. Projeto LMA Brasil 2012-2014. São Paulo: Proadi/Ministério da Saude; 2012. Disponível em: http://www.lmabrasil.com.br/. Acessado em 2015 (20 out). 
Table 1. Principal immunophenotypical markers for acute myeloid leukemia

\begin{tabular}{|l|l|}
\hline Myeloid precursors & CD34, CD38, CD117, CD133, HLA-DR \\
\hline Granulocytic line & CD13, CD 15, CD 16, CD33, CD65, MPOc \\
\hline Monocytic line & CD11c, CD14, CD64, CD4, CD11b, CD36, lisozime \\
\hline Megakaryocytic line & CD41, CD61, CD42 \\
\hline Erythroid line & CD235a (glicoforine A) \\
\hline
\end{tabular}

Chart 1. Principal cytogenetic changes found in acute myeloid leukemia (AML)

\begin{tabular}{|l|}
\hline $\mathrm{t}(8 ; 21)(\mathrm{q} 22 ; \mathrm{q} 22) ;$ RUNX1-RUNX1T1: 5\% of AML cases \\
\hline $\operatorname{inv}(16)(\mathrm{p} 13.1 \mathrm{q} 22) ; \mathrm{t}(16 ; 16)(\mathrm{p} 13.1 ; \mathrm{q} 22) ;$ CBFB-MYH11: $5-8 \%$ of AML cases \\
\hline $\mathrm{t}(15 ; 17)(\mathrm{q} 22 ; \mathrm{q} 12) ;$ PML-RARA: $5-8 \%$ of AML cases \\
\hline $\mathrm{t}(9 ; 11)(\mathrm{p} 22 ; \mathrm{q} 23) ;$ MLLT3-MLL: $9-12 \%$ (children); $2 \%$ (adults) \\
\hline $\mathrm{t}(6 ; 9)(\mathrm{p} 23 ; \mathrm{q} 34) ; \operatorname{inv}(3)(\mathrm{q} 21 \mathrm{q} 26.2) ; \mathrm{t}(3 ; 3)(\mathrm{q} 21 ; \mathrm{q} 26.2) ; \mathrm{t}(1 ; 22)(\mathrm{p} 13 ; \mathrm{q} 13)$ \\
\hline
\end{tabular}

Table 2. FAB (French-American-British) classification based on cytology in seven subtypes of acute myeloid leukemia (AML)

\begin{tabular}{|c|l|}
\hline M1 & $\begin{array}{l}\text { AML without maturation (more than } 90 \% \text { myeloid blasts, with less than } 10 \% \text { of } \\
\text { maturing myeloid elements) }\end{array}$ \\
\hline M2 & $\begin{array}{l}\text { AML with maturation (more than } 30 \% \text { blasts, up to } 89 \% \text { with more than } 10 \% \\
\text { abnormal cells, from promyelocytic to more mature cells) }\end{array}$ \\
\hline M3 & Acute promyelocytic leukemia \\
\hline M4 & $\begin{array}{l}\text { Acute myelomonocytic leukemia (the myeloid blasts must exceed 30\% of the non- } \\
\text { erythroid nucleated medullary cells, with } 20 \% \text { to } 80 \% \text { of them being monoblasts) }\end{array}$ \\
\hline M5 & $\begin{array}{l}\text { Acute monocytic leukemia (more than } 30 \% \text { of the non-erythroid nucleated } \\
\text { medullary cells are blasts, with more than } 80 \% \text { being monocyte precursors) }\end{array}$ \\
\hline M6 & $\begin{array}{l}\text { Acute erythroleukemia or Di Guglielmo's syndrome (more than } 50 \% \text { of the } \\
\text { nucleated elements of the medulla must be erythroblasts and more than 30\% of the } \\
\text { non-erythroid elements must be myeloid blasts) }\end{array}$ \\
\hline M7 & \begin{tabular}{l} 
Acute megakaryocytic leukemia \\
\hline
\end{tabular}
\end{tabular}


Chart 2. World Health Organization (WHO) classification for acute leukemias ${ }^{11}$

\begin{tabular}{|l|}
\hline Acute myeloid leukemia and related cancers \\
\hline Acute myeloid leukemia (AML) with recurrent genetic abnormalities \\
\hline AML with $\mathrm{t}(8 ; 21)(\mathrm{q} 22 ; \mathrm{q} 22) ; R U N X 1-R U N X 1 T 1$ \\
\hline AML with inv(16)(p13.1q22) ou $\mathrm{t}(16 ; 16)(\mathrm{p} 13.1 ; \mathrm{q} 22) ; C B F B-M Y H 11$ \\
\hline AML with $\mathrm{t}(15 ; 17)(\mathrm{q} 22 ; \mathrm{q} 12) ; P M L-R A R A$ \\
\hline AML with $\mathrm{t}(9 ; 11)(\mathrm{p} 22 ; \mathrm{q} 23) ;$ MLLT3-MLL \\
\hline AML with $\mathrm{t}(6 ; 9)(\mathrm{p} 23 ; \mathrm{q} 34) ; D E K-N U P 214$ \\
\hline AML with inv(3)(q21q26.2) ou $\mathrm{t}(3 ; 3)(\mathrm{q} 21 ; \mathrm{q} 26.2) ; R P N 1-E V I 1$ \\
\hline AML (megacarioblastic) with $\mathrm{t}(1 ; 22)(\mathrm{p} 13 ; \mathrm{q} 13) ; R B M 15-M K L 1$ \\
\hline Acute myelogenous leukemia related with myelodysplasia transformation \\
\hline Acute myeloid leukemia without other specific classification: \\
\hline AML with minimal differentiation \\
\hline AML without maturation \\
\hline LMA with maturation \\
\hline Acute myelomonocytic leukemia \\
\hline Acute monoblastic/monocytic leukemia \\
\hline Acute erythroid leukemia \\
\hline Pure erythroid leukemia \\
\hline Erythroleukemia, erythroid/myeloid \\
\hline Acute megakaryoblastic leukemia \\
\hline Acute basophilic leukemia \\
\hline Panmielose with acute myelofibrosis \\
\hline Myeloid sarcoma \\
\hline Myelogenous proliferation related with Down syndrome \\
\hline Myelopoiesis transient abnormal \\
\hline Myelogenous leukemia associated with Down syndrome \\
\hline Blastic plasmacytoid neoplasia of dendritic cells \\
\hline
\end{tabular}


Table 3. Prognosis of acute myeloid leukemia (AML) by karyotype

\begin{tabular}{|l|c|}
\hline \multirow{2}{*}{ Favorable prognosis } & $\mathrm{t}(15 ; 17)$ \\
\cline { 2 - 2 } & $\mathrm{t}(8 ; 21)$ \\
\cline { 2 - 2 } Intermediate prognosis & $\operatorname{Inv}(16)$ and $\mathrm{t}(16: 16)$ \\
\hline \multirow{2}{*}{ Unfavorable prognosis } & normal karyotype \\
\cline { 2 - 2 } & $\mathrm{t}(9 ; 11),-\mathrm{y},+8,+6$, del $12(\mathrm{p})$ \\
\cline { 2 - 2 } & $\mathrm{t}(6 ; 9),-7,-5$ \\
\hline
\end{tabular}

Table 4. European Leukemia Net prognostic classification ${ }^{17}$

\begin{tabular}{|c|c|}
\hline Genetic group & Changes \\
\hline \multirow{4}{*}{ Favorable } & $\mathrm{t}(8: 21)(\mathrm{q} 22 ; \mathrm{q} 22), \mathrm{RUN} X 1-\mathrm{RUNX} 1 \mathrm{~T} 1$ \\
\hline & $\operatorname{Inv}(16)(\mathrm{p} 13.1 \mathrm{q} 22)$ or $\mathrm{t}(16 ; 16)(\mathrm{p} 13.1 ; \mathrm{q} 22) ;$ CBFB- MYH11 \\
\hline & NPM1 mutated without FLT3-ITD (normal karyotype) \\
\hline & CEBPA mutated (normal karyotype) \\
\hline \multirow{3}{*}{ Intermediate I } & NPM1 e FLT3-ITD mutated (normal karyotype) \\
\hline & NPM1 e FLT3 negativos (normal karyotype) \\
\hline & NPM1 negative and FLT3 positive (normal karyotype) \\
\hline \multirow{2}{*}{ Intermediate II } & $\mathrm{t}(9: 11)(\mathrm{p} 22 ; \mathrm{q} 23) ;$ MLLT3-MLL \\
\hline & Cytogenetic findings not classified as favorable or adverse \\
\hline \multirow{7}{*}{ Adverse } & $\operatorname{Inv}(3)(\mathrm{q} 21 \mathrm{q} 26.2)$ or $\mathrm{t}(3 ; 3)(\mathrm{q} 21: \mathrm{q} 26.2) ; \mathrm{RPN} 1-\mathrm{EVI} 1$ \\
\hline & $\mathrm{t}(6 ; 9)(\mathrm{p} 23 ; \mathrm{q} 34) ;$ DEK-NUP 214 \\
\hline & $\mathrm{t}(\mathrm{v} ; 11)(\mathrm{v} ; \mathrm{q} 23)$; rearrangement MLL \\
\hline & -5 or del $(5 q)$ \\
\hline & -7 \\
\hline & anl $(17 p)$ \\
\hline & complex karyotype \\
\hline
\end{tabular}


Figure 1. Consolidation therapy for patients with acute myeloid leukemia (AML)

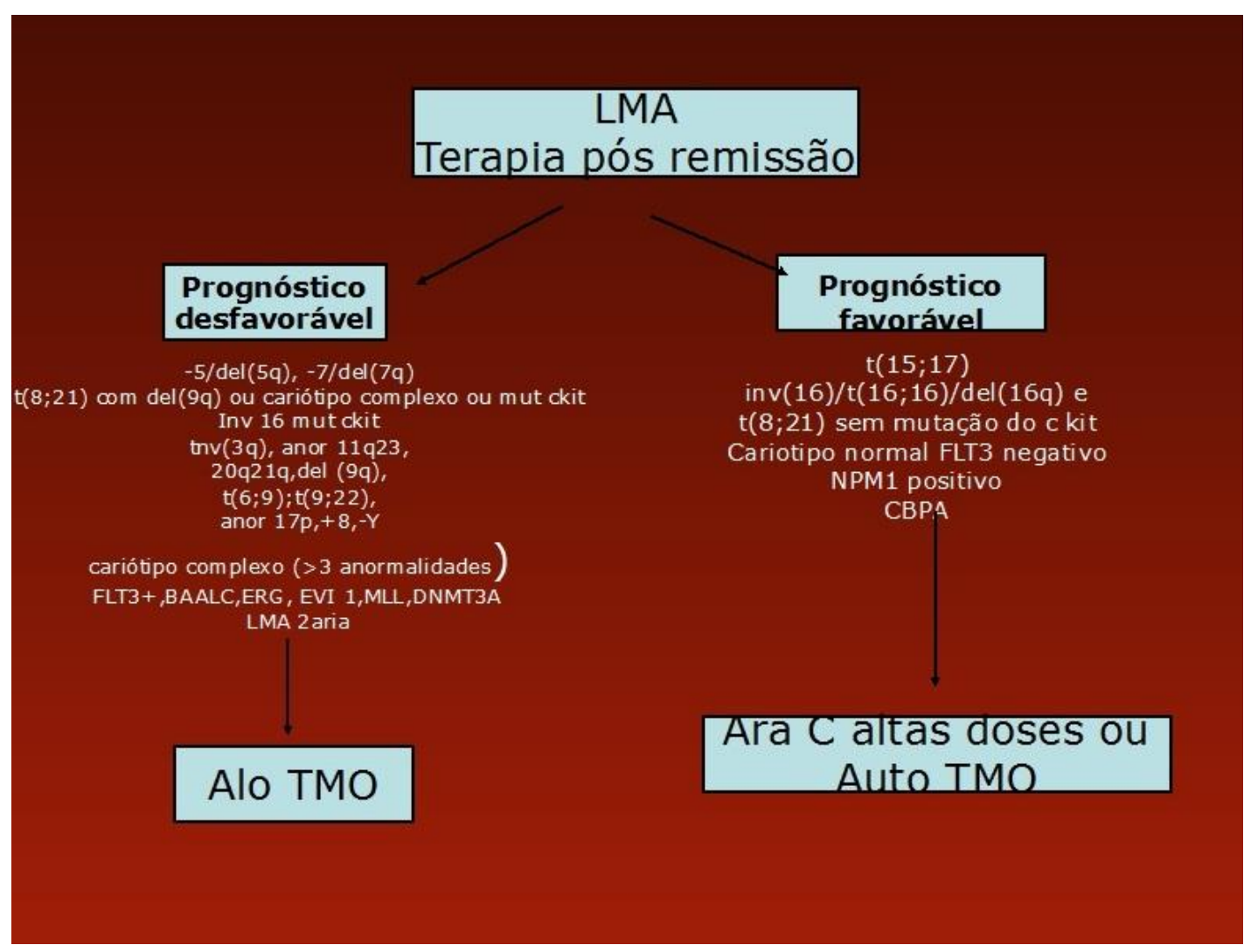


Figure 2. Allogeneic transplants in Brazil. Overall survival, survival by first remission, second remission, and advanced disease and by de novo or secondary disease.
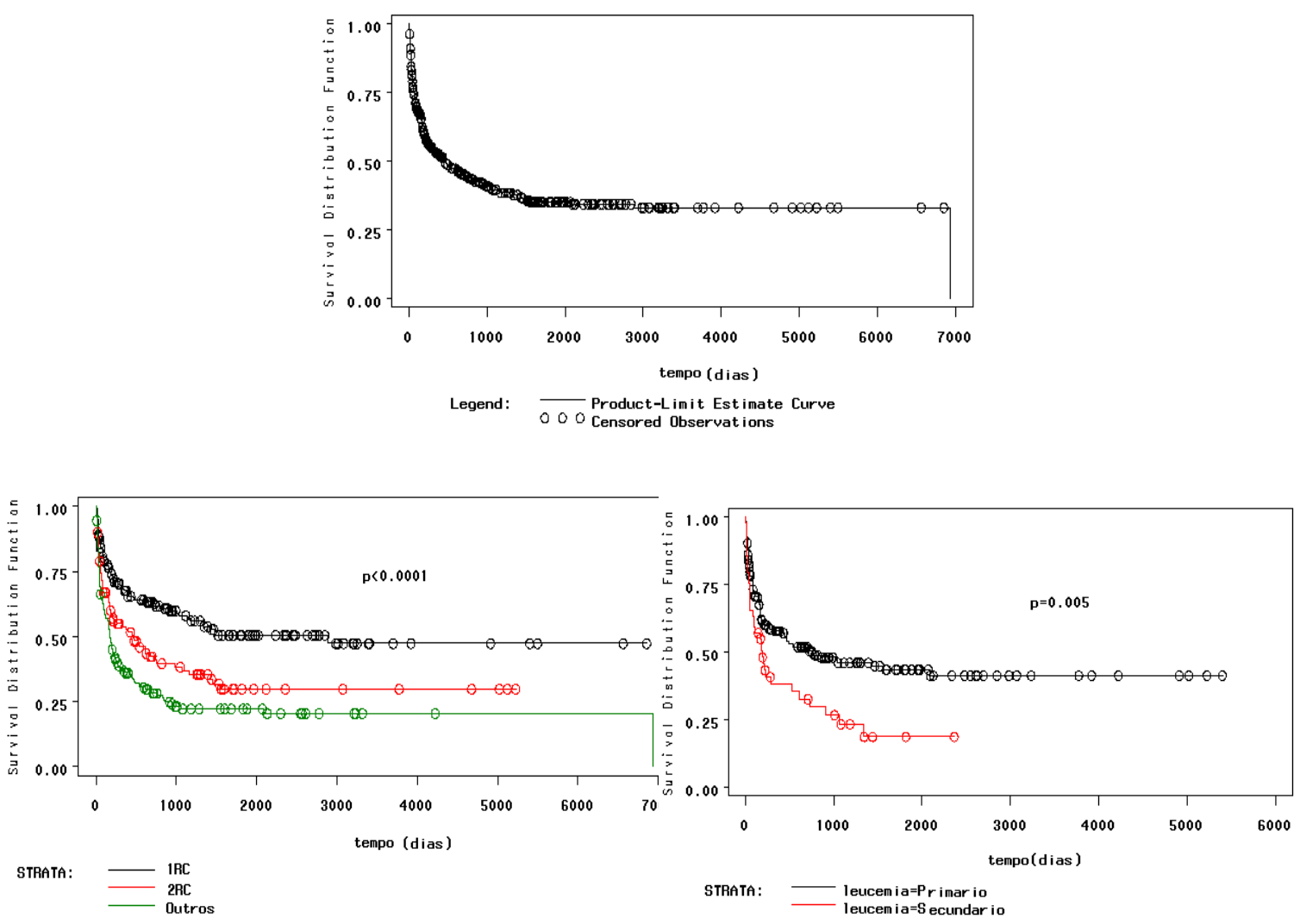
Figure 3. Autologous transplants in Brazil. Overall survival, survival by first remission, second remission, and advanced disease and by de novo or secondary disease.
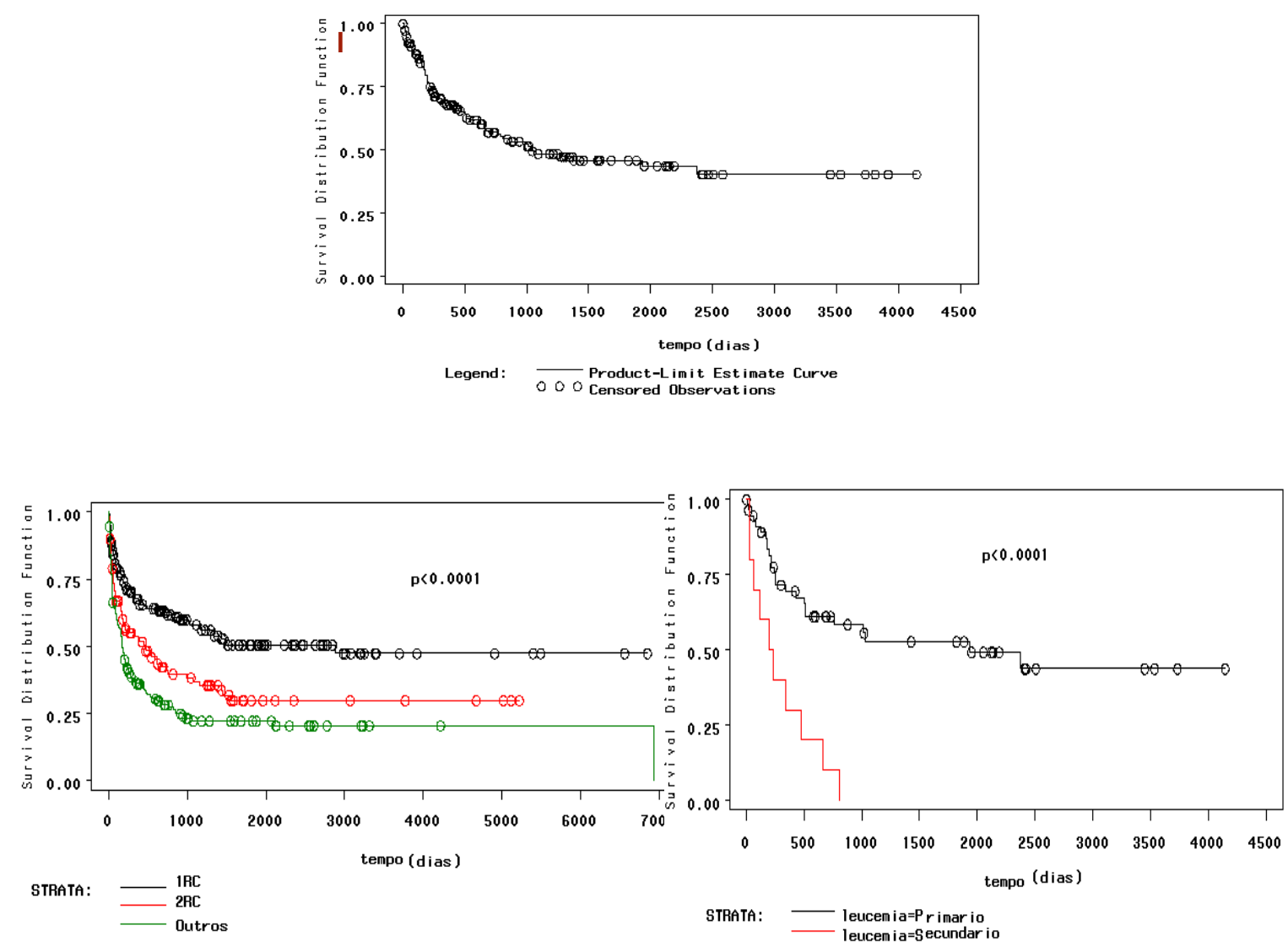
Figure 4. Data presented by Marcelo Pasquini, of the Center for International Blood and Marrow Transplant Research (CIBMTR), classifying the transplants of Brazilian centers that submitted data to the international registry.

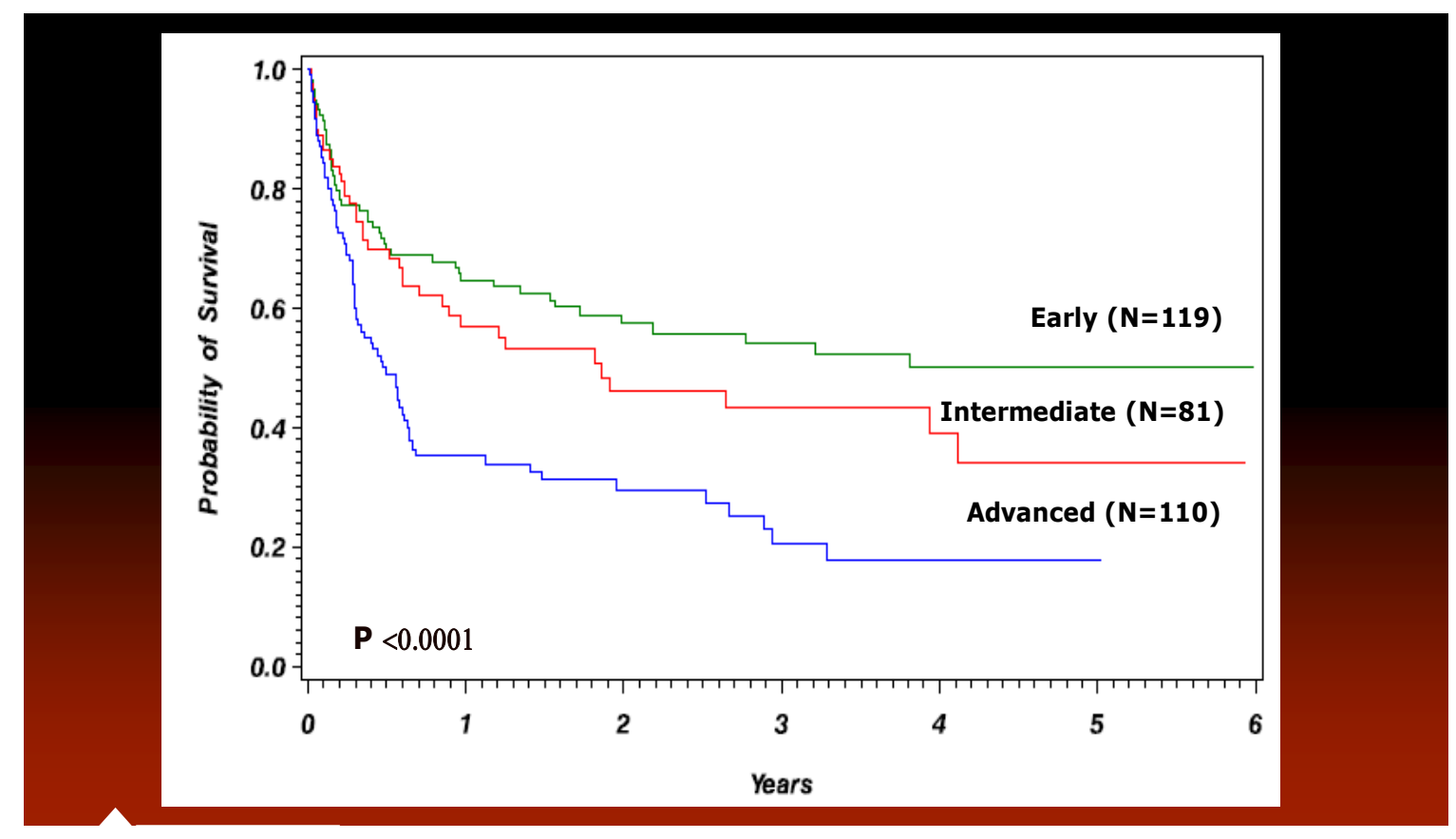


Figure 5. Survival curve with the use of oral busulfan and fludarabine in a group study directed by the Centro de Transplantes de Jaú.

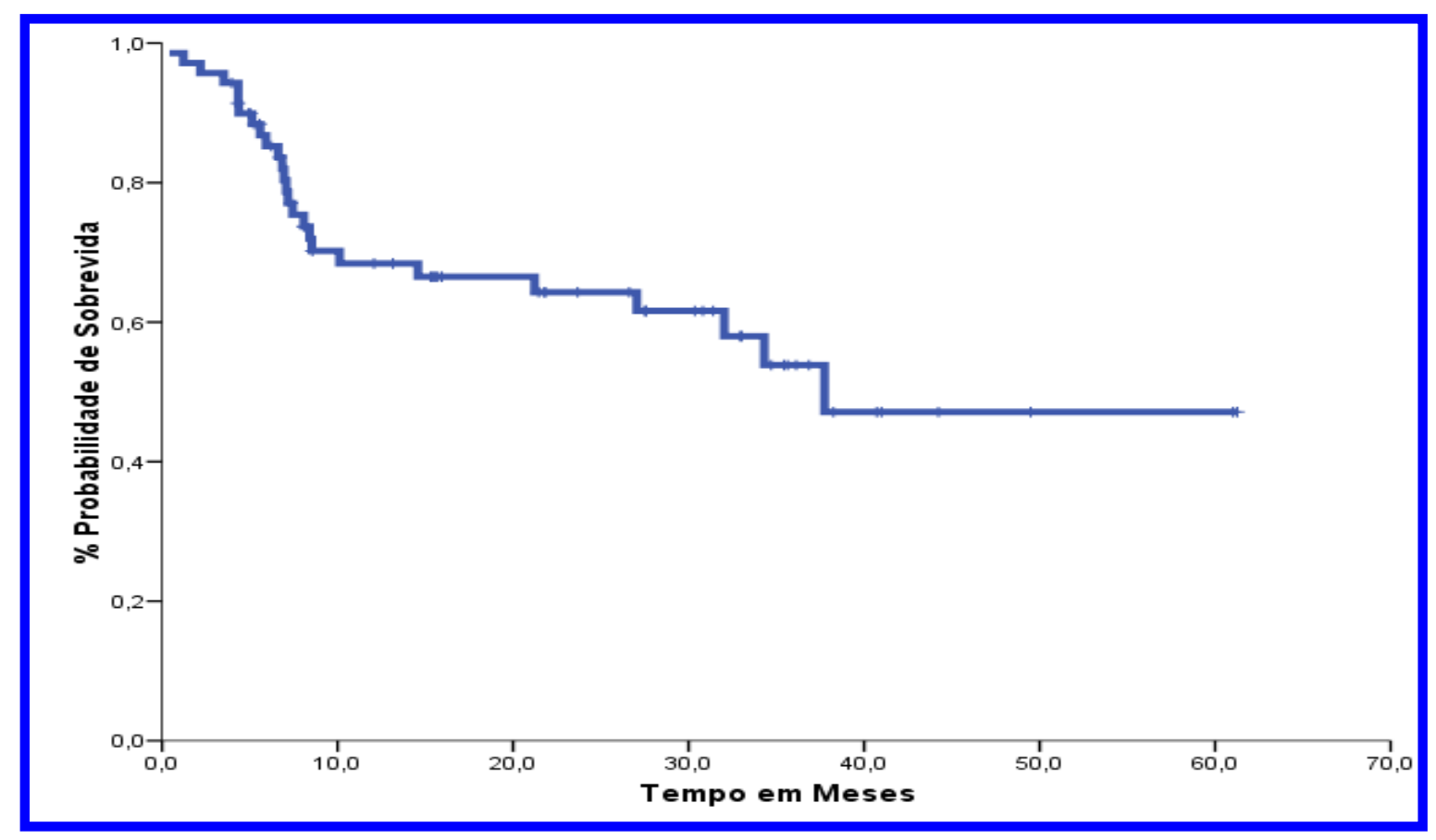


Figure 6. Overall survival with intravenous busulfan (BU) and fludarabine (FLU) in patients with acute myeloid leukemia (AML).

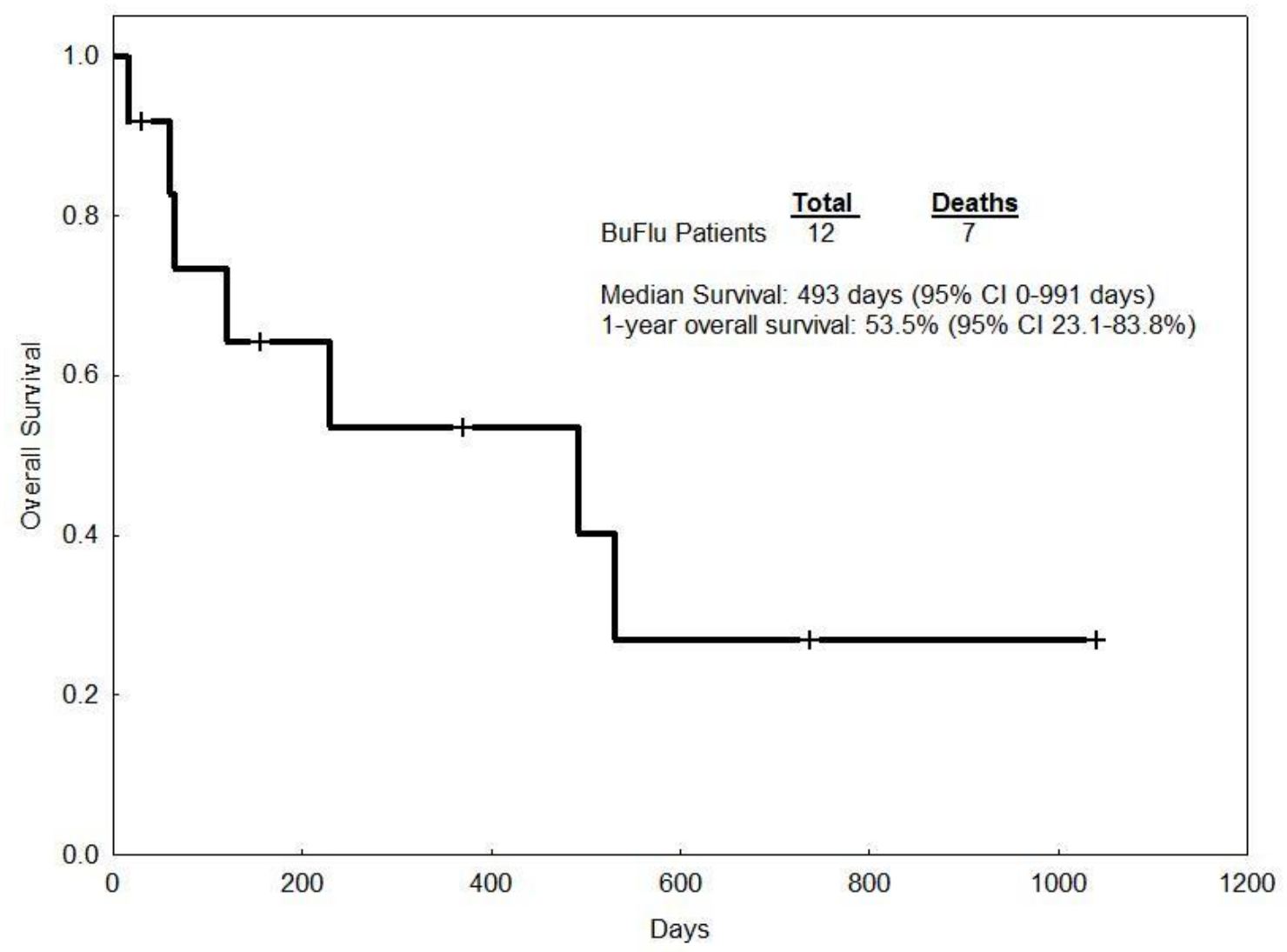


Figure 7. Main adverse effects from the use of busulfan (BU) and fludarabine (FLU) conditioning, showing few serious changes

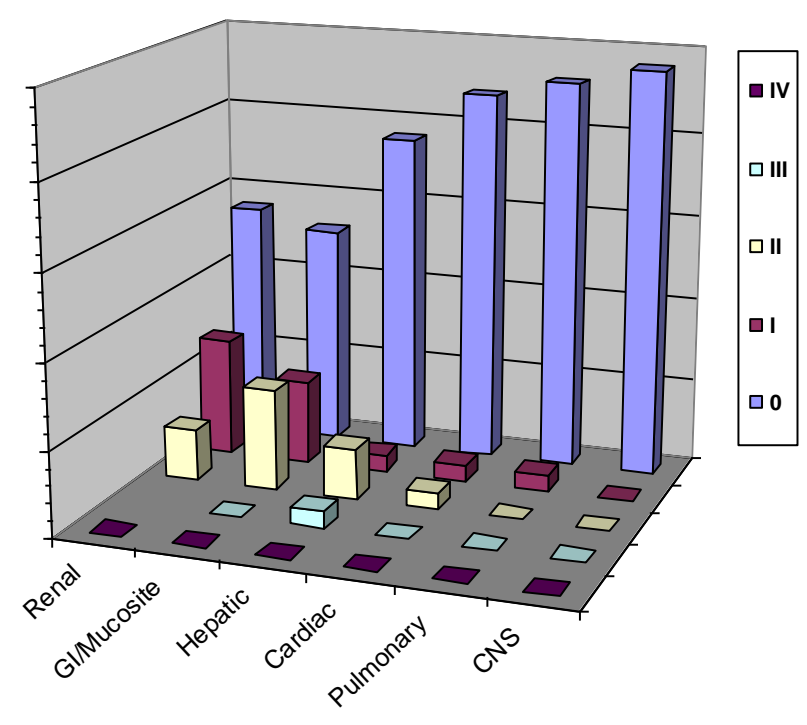


Figure 8. A: Overall survival and disease-free survival. B: Cumulative incidence of recurrence and deaths unrelated to recurrence
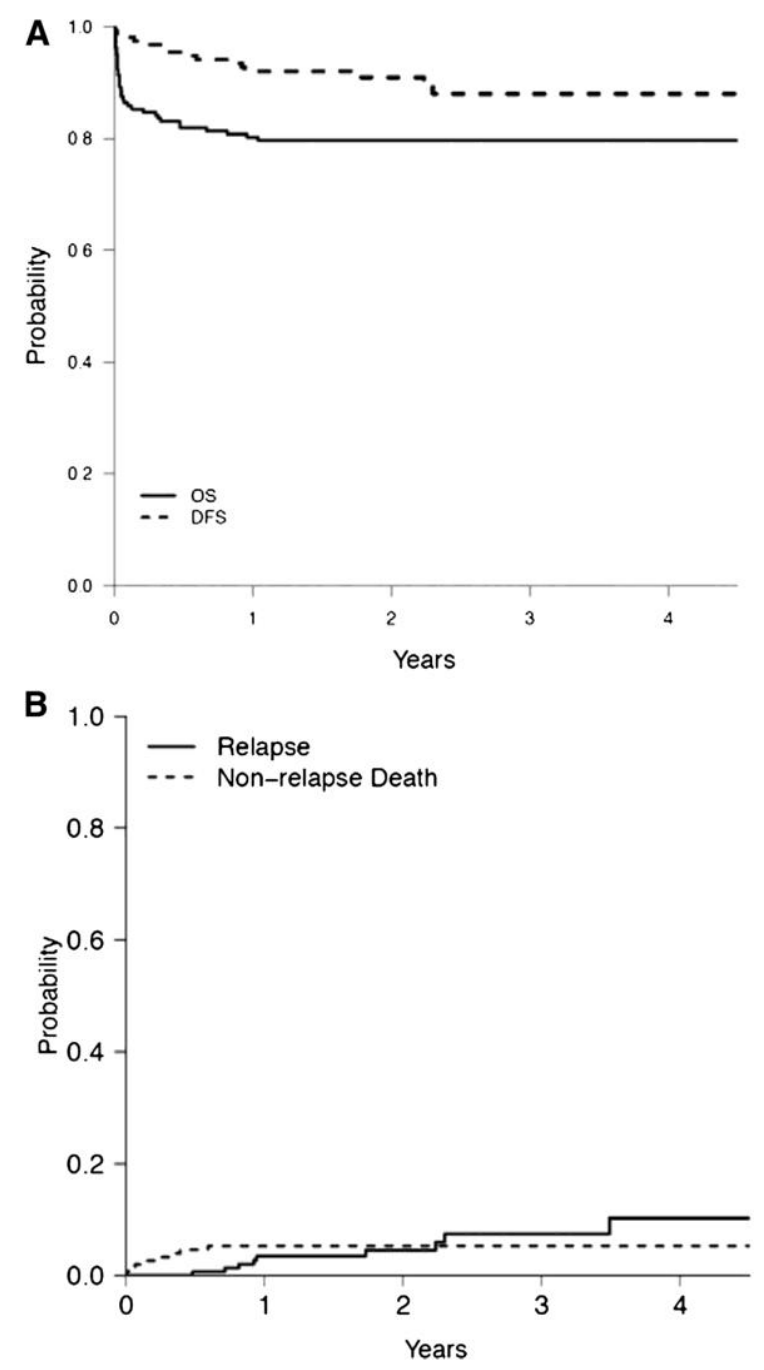
Figure 9. European Leukemia Net risk classification in 100 patients with acute myeloid leukemia (AML) studied in the Brazil AML project.

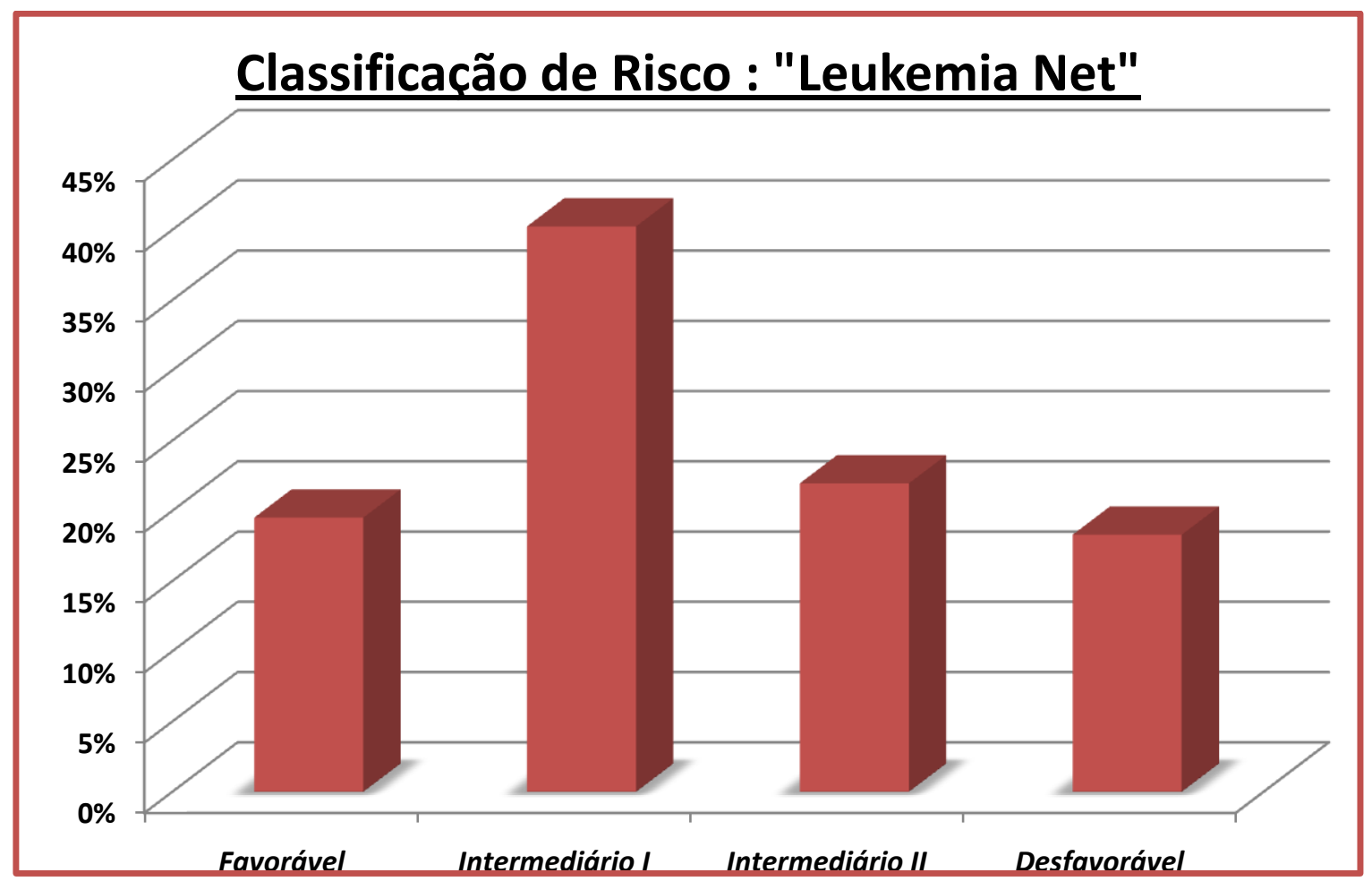

